Jurnal Pemikiran Masyarakat Ilmiah Berwawasan Agribisnis. 2017. 3(2): 150-168

\title{
HUBUNGAN TINGKAT PARTISIPASI ANGGOTA DENGAN KINERJA GABUNGAN KELOMPOK TANI (Suatu Kasus di Gapoktan Kopi Arjuna, Kecamatan Lembang, Kabupaten Bandung Barat)
}

\author{
INTAN GITA MUSTIKA, LIES SULISTYOWATI \\ Departemen Sosial-Ekonomi Fakultas Pertanian Universitas Padjadjaran \\ Email: intangitam@gmail.com
}

\begin{abstract}
ABSTRAK
Gapoktan Kopi Arjuna merupakan salah satu gabungan kelompok tani kopi yang berlokasi di Kecamatan Lembang Kabupaten Bandung Barat. Dalam perkembangannya Gapoktan mengalami kemunduran dalam kekompakan antar anggota Gapoktan, yang selanjutnya berpengaruh terhadap tingkat partisipasi dan kinerja Gapoktan. Penelitian ini bertujuan untuk mengkaji hubungan manfaat yang diperoleh anggota dengan tingkat partisipasi anggota Gapoktan, dan hubungan tingkat partisipasi anggota Gapoktan dengan kinerja Gapoktan. Desain penelitian menggunakan pendekatan kuantitatif, sedangkan pengambilan responden menggunakan teknik purposive. Metode analisis menggunakan korelasi Rank Spearman dan analisis deskriptif. Berdasarkan hasil penelitian diperoleh bahwa manfaat yang diperoleh anggota adalah kerjasama yang baik dengan pengurus, berhubungan baik dengan sesama anggota, mengikuti kegiatan pembinaan dan pelatihan, jaminan pemasaran kopi dan peningkatan pendapatan. Tingkat partisipasi anggota yang tinggi adalah menjual kopi ke Gapoktan. Hasil uji korelasi antara manfaat yang diperoleh anggota dan tingkat partisipasi anggota menunjukkan hubungan yang signifikan dan termasuk kategori korelasi yang lemah. Demikian juga korelasi antara tingkat partisipasi anggota dan kinerja Gapoktan menunjukkan hubungan yang signifikan dan termasuk kategori korelasi yang lemah.
\end{abstract}

Kata kunci : Manfaat, tingkat partisipasi, kinerja Gapoktan, kopi.

\section{ABSTRACT}

Arjuna Coffee farmer's group is one of the coffee farmer's groups that located in Lembang District, West Bandung Regency. As the time goes by, there was a problem in farmer's groups which is the lack of solidarity among the member that will affect the member's participation level and farmer's group's performance. Therefore, this research aimed to analyze the benefits that gained by the members of the farmer's groups, the participation level of the member, the relation between the benefits and the participation level, and the relation between the participation level and farmers group's performance. This research used quantitative approach, and the method of analysis used spearman correlation rank and descriptive. The result of research, it is found that the benefits that gained by the members are the good cooperation with the staff, a good relationship with the fellow members, got the guidance and training activities, marketing guarantee, and the income increases. The high participation level is to sell coffee to farmer's groups. The result of correlation test between the benefits and the participation level shows significant correlation between two of them that classified as the category of a weak correlation. The result is also implied to the correlation test between member participation level and farmers group's performance.

Keywords: Benefit, participation level, performance of farmers group's, coffee. 
Hubungan Tingkat Partisipasi Anggota dengan Kinerja Gabungan Kelompok Tani INTAN GITA MUSTIKA, LIES SULISTYOWATI

PENDAHULUAN

Kopi merupakan salah satu komoditi yang banyak dibudidayakan oleh negara yang berada di kawasan tropis Benua Afrika, Amerika Tengah dan Selatan serta di Asia Pasifik. Keberadaan komoditas kopi ini banyak diusahakan oleh banyak pihak sesuai dengan tingkat kebutuhan baik dari sisi jumlah maupun jenisnya, sehingga terdapat dua jenis kopi yang banyak dikenal, yaitu kopi arabika dan kopi robusta. Berdasarkan dua jenis kopi tersebut, kopi arabika merupakan bagian terbesar dari jenis kopi yang dihasilkan, yaitu sekitar $70 \%$ dari jumlah produksi dan sisanya $30 \%$ kopi robusta.

Pada saat ini terdapat 4 kawasan yang menjadi sentra produksi kopi di Indonesia, yaitu Nangroe Aceh Darussalam, Sumatera Utara, Jawa Timur, dan Sulawesi Selatan. Di samping daerahdaerah tersebut, penyebaran kopi semakin luas seperti di Jawa Barat. Berdasarkan data Dinas Perkebunan Jawa Barat tahun 2015, pertambahan luas lahan untuk kopi arabika adalah 1,39 Ha/tahun, dan untuk kopi robusta adalah 1,99 Ha/tahun. Sedangkan perkembangan produksi kopi arabika sempat menurun di tahun 2014 dan perkembangan produksi kopi robusta terus meningkat tiap tahunnya. Sehingga, dapat diketahui pertambahan produksi kopi arabika adalah 4,02 ton/tahun dan kopi robusta 12,94 ton/tahun .
Kabupaten Bandung Barat merupakan salah satu daerah penghasil kopi arabika dan kopi robusta di Jawa Barat. Berdasarkan data statistik Dinas Perkebunan Jawa Barat, kopi arabika di Kabupaten Bandung Barat menempati posisi ke 4 dalam jumlah produksi dan luas perkebunan kopi setelah Kabupaten Bandung, Kabupaten Garut dan Kabupaten Bogor.

Kopi arabika asal Kabupaten Bandung Barat ternyata sudah diakui dunia. Menurut Ketua Asosiasi Petani Kopi Indonesia (APEKI), kopi asal Kabupaten Bandung Barat mendapatkan peringkat kedua pada Specialty Coffee Association of America Expo 2016 di Atlanta, Georgia, Amerika Serikat. Kopi peringkat pertama juga berasal dari Jawa Barat, tepatnya Kabupaten Bandung.

Potensi yang ada di Kabupaten Bandung perlu dikembangkan untuk meningkatkan pendapatan petani kopi. Untuk itu diperlukan peranan kelompok tani yang mampu: meningkatkan kemampuan petani baik pengetahuan maupun keterampilan budidaya, pemanfaatan lahan, akses dan ketersediaan modal serta pemasaran hasil produksi. Untuk meningkatkan skala usaha dan peningkatan usaha ke arah komersial, kelompok tani dapat dikembangkan melalui kerjasama antar kelompok dengan membentuk Gapoktan. Gapoktan adalah 


\section{MIMBAR AGRIBISNIS}

Jurnal Pemikiran Masyarakat Ilmiah Berwawasan Agribisnis. 2017. 3(2): 150-168

gabungan beberapa petani atau kelompok tani yang melakukan usaha agribisnis diatas prinsip kebersamaan dan kemitraan sehingga mencapai peningkatan produksi dan pendapatan usahatani bagi anggotanya dan petani lainnya (Syahyuti, 2007).

Gapoktan Kopi Arjuna merupakan sebuah gabungan kelompok tani kopi yang berlokasi di Kecamatan Lembang, Kabupaten Bandung Barat, Provinsi Jawa Barat, yang dibentuk pada November 2008. Pada tahun 2008, Gapoktan Kopi Arjuna belum memiliki anggota yang tetap dan juga memiliki anggota yang sedikit. Baru pada tahun 2012 mulai memiliki anggota dan mulai menanam secara serempak. Jumlah kelompok tani sebanyak 13 kelompok tani dengan total anggota 264 orang. Luas areal kebun total sebanyak 349 Ha dengan jumlah tanaman 721.000 pohon. Untuk varietas kopi arabika memiliki luas areal kebun $201 \mathrm{Ha}$ dengan jumlah tanaman 412.500 pohon, sedangkan untuk varietas kopi robusta memiliki luas areal kebun 148 Ha dengan jumlah tanaman 308.500 pohon.

Berdasarkan hasil pra survey di lapangan diperoleh informasi bahwa telah terjadi permasalahan yang tidak sesuai dengan harapan awal atau cita-cita didirikannya Gapoktan Kopi Arjuna. Masalah yang dimaksud adalah berkurangnya kekompakan di antara Gapoktan Kopi Arjuna dengan para kelompok tani beserta anggotanya. Menurut ketua Gapoktan Kopi Arjuna, permasalahan ini muncul pada awal tahun 2016. Hal ini disebabkan dengan adanya permainan broker, yakni pedagang besar yang langsung membeli kopi dari petani dengan harga yang ditawarkan lebih tinggi dibanding harga yang ditawarkan oleh Gapoktan. Sehingga terjadilah kekurangan kekompakan yang terjadi pada beberapa anggota Gapoktan Kopi Arjuna. Menurut Fauziyah (2011), bahwa semakin rendah kekompakan anggota maka tujuan Gapoktan yang telah ditetapkan tidak tercapai, sehingga kinerja Gapoktan semakin kurang berkembang. Maka dari itu diduga terdapat hubungan antara kekompakan anggota yang berhubungan dengan kinerja Gapoktan Kopi Arjuna.

Ketua Gapoktan Kopi Arjuna juga menyadari bahwa Gapoktan kurang memiliki kemampuan dan kurang berperan dalam melaksanakan seluruh fungsinya. Menurut Fauziyah (2011), hal ini akan berpengaruh terhadap partisipasi anggota Gapoktan, karena fungsi Gapoktan akan berjalan secara optimal apabila seluruh anggota Gapoktan ikut berpartisipasi pada setiap kegiatan yang diadakan oleh Gapoktan. Partisipasi anggota dalam Gapoktan Kopi Arjuna dapat dilihat dari partisipasi di bidang usaha dan organisasi.

Permasalahan partisipasi anggota yang terjadi di Gapoktan Kopi Arjuna 
Hubungan Tingkat Partisipasi Anggota dengan Kinerja Gabungan Kelompok Tani INTAN GITA MUSTIKA, LIES SULISTYOWATI

dilihat dari partisipasi anggota di bidang organisasi usaha dan organisasi. Partisipasi anggota di bidang usaha terlihat dari banyaknya anggota Gapoktan Kopi Arjuna yang menjual kopinya ke broker, sehingga pasokan kopi ke Gapoktan Kopi Arjuna menjadi berkurang. Sedangkan partisipasi di bidang organisasi dilihat dari adanya beberapa ketua kelompok tani yang sudah tidak pernah menghadiri acara/kegiatan yang diselenggarakan oleh Gapoktan.

Berdasarkan Peraturan Menteri Pertanian

Nomor

273/Kpts/OT.160/4/2007, kemampuan Gapoktan memenuhi kebutuhan anggota, kemampuan Gapoktan memberikan nilai tambah kepada anggota dan kepercayaan bahwa Gapoktan akan memberi manfaat dan keuntungan kepada anggota akan meningkatkan partisipasi atau peran anggota. Partisipasi anggota akan timbul karena manfaat sosial dan ekonomi yang diperoleh anggota. Peningkatan pendapatan merupakan salah satu manfaat ekonomi yang diperoleh anggota yang akan meningkatkan partisipasi anggota. Sedangkan, manfaat sosial yang diperoleh anggota semakin tinggi maka keinginan untuk berpartisipasi akan semakin tinggi. Oleh karena itu perlu dilakukan analisis manfaat sosial dan ekonomi untuk melihat pengaruhnya terhadap tingkat partisipasi anggota Gapoktan Kopi Arjuna.
Berdasarkan uraian di atas, agar Gapoktan Kopi Arjuna berjalan sesuai dengan harapan atau cita-cita awal, maka perlu dilakukan evaluasi kinerja Gapoktan Kopi Arjuna. Kinerja diduga dipengaruhi oleh partisipasi anggota di bidang usaha dan organisasi, selanjutnya tingkat partisipasi diduga dipengaruhi oleh manfaat sosial dan ekonomi yang diperoleh anggota.

\section{METODE PENELITIAN}

\section{Objek dan Tempat Penelitian}

Objek yang diteliti mengenai manfaat yang diperoleh anggota Gapoktan, tingkat partisipasi beserta hubungannya dengan manfaat, dan pengaruh partisipasi terhadap kinerja Gapoktan di Gapoktan Kopi Arjuna. Penelitian ini dilakukan di Gapoktan Kopi Arjuna yang terletak di Desa Suntenjaya Kecamatan Lembang, Kabupaten Bandung Barat.

\section{Desain dan Teknik Penelitian}

Desain penelitian ini dilakukan dengan menggunakan desain kuantitatif. Menurut Sugiyono (2012), desain kuantitatif berlandaskan pada filsafat positivisme, digunakan untuk meneliti pada populasi atau sampel tertentu, pengumpulan data menggunakan instrument penelitian, analisis data bersifat kuantitatif/statistik, dengan tujuan untuk menguji hipotesis yang telah ditetapkan. 


\section{MIMBAR AGRIBISNIS}

Jurnal Pemikiran Masyarakat Ilmiah Berwawasan Agribisnis. 2017. 3(2): 150-168

Teknik penelitian ini dilakukan dengan menggunakan metode survey. Menurut Sugiyono (2012), metode survey digunakan untuk mendapatkan data dari tempat tertentu yang alamiah, tetapi peneliti melakukan perlakuan dalam pengumpulan data melalui kuesioner dan wawancara.

\section{Sumber Data dan Cara Penentuannya}

Data yang diperlukan dalam penelitian ini terdiri atas data primer dan sekunder. Cara menentukan sumber data, tahapan pertama adalah menentukan kelompok tani secara purposive sampling pada level kelompok tani, yaitu dari jumlah tanaman kopi yang dimiliki oleh kelompok tani. Dari sebanyak 13 kelompok tani diambil dua kelompok tani, yaitu satu kelompok tani yang memiliki jumlah tanaman kopi tertinggi dan satu kelompok tani yang memiliki jumlah tanaman kopi terendah. Tahapan kedua, dalam penentuan responden pada penelitian ini dilakukan dengan metode sensus pada level petani

\section{Teknik Analisis Data}

\section{Uji Validitas}

Validitas adalah tingkat dimana satu instrumen ukur digunakan untuk mengukur apa yang diharapkan. Hasil pengujian validitas terhadap seluruh butir pernyataan pada variabel manfaat ekonomi, menunjukkan ada satu pertanyaan yang tidak valid. Butir pernyataan yang tidak valid tersebut adalah pernyataan untuk indikator bantuan kredit. Selanjutnya butir pernyataan yang tidak valid tersebut tidak akan dipergunakan dalam pengujian data selanjutnya.

\section{Uji Reliabilitas}

Pengujian reliabilitas digunakan untuk mengukur objek yang sama walaupun dilakukan beberapa kali hasilnya tetap data yang sama (Sandjojo, 2014). Hasil uji reabilitas menggunakan rumus Alpha Cronbach menunjukkan bahwa pernyataan yang digunakan pada instrumen penelitian sudah termasuk kategori reliabel atau dapat dipercaya.

\section{Analisis Manfaat Sosial dan Ekonomi}

Manfaat ekonomi terdiri atas jaminan pemasaran kopi, harga beli kopi, peningkatan pendapatan, kemudahan memperoleh saprotan dan penerimaan bantuan kredit. Sedangkan, manfaat sosial terdiri atas kerjasama dan hubungan yang baik dengan sesama anggota serta peningkatan pengetahuan melalui penyuluhan. Besar range untuk tiap kelas yang diteliti adalah:

$$
\begin{aligned}
\text { Range } & =\frac{\text { (nilai tertinggi-nilai terendah })}{\text { Kelas }} \\
& =\frac{150-50}{3}=33,33=33
\end{aligned}
$$


Hubungan Tingkat Partisipasi Anggota dengan Kinerja Gabungan Kelompok Tani INTAN GITA MUSTIKA, LIES SULISTYOWATI

Sehingga pembagian kelas berdasarkan pengukuran manfaat sosial dan ekonomi yang diperoleh anggota adalah:

a) $50-83:$ Kategori tidak merasakan

b) 84 - 117 : Kategori kurang merasakan

c) $118-151:$ Kategori merasakan

\section{Analisis Partisipasi Anggota}

Tingkat partisipasi anggota Gapoktan dilihat dari pastisipasi organisasi dan usaha. Partisipasi anggota dalam bidang organisasi dilihat dari kehadiran anggota dalam Rapat Anggota Tahunan (RAT), keaktifan anggota dalam memberikan saran kepada pengurus Gapoktan dan memanfaatkan fasilitas Gapoktan. Partisipasi anggota di bidang usaha dilihat dari keaktifan anggota dalam bertransaksi usaha melalui Gapoktan. Besar range untuk tiap kelas yang diteliti adalah:

$$
\begin{aligned}
\text { Range } & =\frac{(\text { nilai tertinggi-nilai terendah })}{\text { Kelas }} \\
& =\frac{105-35}{3}=23,33=23
\end{aligned}
$$

Sehingga pembagian kelas berdasarkan pengukuran tingkat partisipasi anggota adalah:
a) $50-83$ : Kategori tidak aktif
b) $84-117$ : Kategori kurang aktif
c) $118-151:$ Kategori aktif

\section{Analisis Korelasi Rank Spearman}

Korelasi Rank Spearman dalam penelitian ini digunakan untuk mengetahui hubungan manfaat yang diperoleh anggota terhadap tingkat partisipasi anggota dan hubungan tingkat partisipasi anggota terhadap kinerja Gapoktan

Penggunaan metode korelasi Rank Spearman adalah untuk membuktikan berhubungan atau tidaknya antara masingmasing variabel. Analisis data dalam penelitian ini menggunakan aplikasi SPSS 16.0 for windows dengan rumus:

$$
\mathrm{r}_{\mathrm{s}}=1-\frac{6 \sum_{i=0}^{n} d i^{2}}{n\left(n^{2}-1\right)}
$$

Dimana:

$\mathrm{r}_{\mathrm{s}}=$ koefisien korelasi Rank Spearman

$\mathrm{di}=$ selisih antara peringkat $\mathrm{X}$ dan $\mathrm{Y}$

$\mathrm{n}=$ jumlah sampel

Tanda positif pada nilai $r_{s}$ menunjukkan adanya hubungan searah antara variabel $\mathrm{X}$ dan $\mathrm{Y}$, sedangkan tanda negatif pada nilai $r_{s}$ menunjukkan adanya hubungan berlawanan arah antara variabel $X$ dan variabel $Y$. Kriteria pengujian hubungan observasi dilakukan pada taraf nyata $1 \%-5 \%$.

Secara deskriptif nilai $r_{\mathrm{s}}$ dapat dikategorikan menjadi beberapa kategori sebagai berikut (Siegel, 2011).

1. Bila $0<r_{\mathrm{s}}<0,2$ atau $-0,2>\mathrm{r}_{\mathrm{s}}>0$, maka kedua variabel berkorelasi sangat lemah.

2. Bila $0,2<r_{\mathrm{s}}<0,4$ atau $-0,2>\mathrm{r}_{\mathrm{s}}>-0,4$, maka kedua variabel berkorelasi lemah. 
Jurnal Pemikiran Masyarakat Ilmiah Berwawasan Agribisnis. 2017. 3(2): 150-168

3. Bila $0,4<r_{s}<0,6$ atau $-0,4>r_{s}>-0,6$, maka kedua variabel berkorelasi sedang.

4. Bila $0,6<\mathrm{r}_{\mathrm{s}}<0,8$ atau $-0,6>\mathrm{r}_{\mathrm{s}}>-0,8$, maka kedua variabel berkorelasi kuat.

5. Bila $0,8<\mathrm{r}_{\mathrm{s}}<1$ atau $-0,8>\mathrm{r}_{\mathrm{s}}>1$, maka kedua variabel berkorelasi sangat kuat.

Kriteria pengambilan keputusan:

$\mathrm{H}_{0}$ : Jika $\mathrm{r}_{\mathrm{s}}=0$, maka tidak terdapat hubungan

$\mathrm{H}_{1}$ : Jika $\mathrm{r}_{\mathrm{s}} \neq 0$, maka terdapat hubungan

\section{HASIL DAN PEMBAHASAN}

\section{Analisis Manfaat yang Diperoleh} Anggota Gapoktan Kopi Arjuna

\section{a. Analisis Manfaat Sosial Anggota Gapoktan Kopi Arjuna}

Keberadaan Gapoktan Kopi Arjuna memberikan manfaat sosial bagi anggotanya. Manfaat sosial merupakan manfaat yang diperoleh secara sosial, yaitu adanya kerjasama yang baik dengan pengurus, hubungan yang baik dengan sesama anggota serta kegiatan pembinaan dan pelatihan. Manfaat sosial memberikan gambaran adanya sikap kebersamaan dan hubungan harmonis antar sesama manusia dalam mengembangkan diri sehingga manfaat sosial juga memberikan motivasi kepada setiap anggota untuk berpartisipasi. Hasil analisis dapat dilihat pada Tabel 1.

Berdasarkan Tabel 1, terlihat bahwa sebagian besar responden merasakan adanya manfaat sosial. Sebanyak 92\% responden merasakan hubungan baik dengan sesama anggota Gapoktan. Hubungan yang baik sesama anggota Gapoktan diindikasikan oleh saling mengenal sesama anggota. Hal ini karena intensitas pertemuan dengan sesama anggota Gapoktan adalah bertemu setiap hari. Pertemuan antar anggota Gapoktan bukan pertemuan secara resmi, melainkan mereka bertemu saat perjalanan menuju kebun. Kebun mereka berdekatan satu sama lain sehingga terjadi hubungan yang baik seperti saling menyapa, berbagi informasi dan saling membantu.

Tabel 1. Hasil Analisis Manfaat Sosial Anggota Gapoktan Kopi Arjuna

\begin{tabular}{|c|c|c|c|c|c|c|}
\hline \multirow{2}{*}{ No } & \multirow{2}{*}{ Indikator Manfaat Sosial } & \multicolumn{3}{|c|}{ Skor Manfaat } & \multirow{2}{*}{ Total Skor } & \multirow{2}{*}{$\begin{array}{l}\text { Kategori } \\
\text { Manfaat }\end{array}$} \\
\hline & & 1 & 2 & 3 & & \\
\hline 1 & Kerjasama yang baik dengan pengurus & 0 & 4 & 46 & 146 & Merasakan \\
\hline 2 & $\begin{array}{l}\text { Hubungan yang baik dengan sesama } \\
\text { anggota }\end{array}$ & 0 & 3 & 47 & 147 & Merasakan \\
\hline 3 & Kegiatan pembinaan dan pelatihan & 0 & 5 & 45 & 145 & Merasakan \\
\hline & Kerjasama yang baik dengan & \multicolumn{3}{|c|}{ responden } & merasakan & manfaatnya. \\
\hline
\end{tabular}


dapat diindikasikan dengan seringnya bertemu dan menjaga komunikasi antara anggota pengurus. Pertemuan ini bersifat tidak resmi, dimana pengurus Gapoktan bertemu dengan anggota Gapoktan pada saat mengirimkan hasil panen kopi. Pertemuan yang dilakukan antara pengurus dengan anggota Gapoktan secara resmi dilakukan jika terdapat suatu masalah yang harus diselesaikan bersama-sama. Berdasarkan hasil wawancara dengan pengurus Gapoktan dapat dikatakan bahwa pertemuan antara pengurus dan anggota Gapoktan diadakan setiap akhir tahun atau pada saat ada program bantuan dari pemerintah dan sosialisasi programprogram kerja Gapoktan. Namun saat ini mengalami penurunan intensitas bertemu yang semakin jarang. Kurangnya program bantuan dari pemerintah dan minimnya penyuluhan, menjadi penyebab berkurangnya intensitas pengurus dan anggota Gapoktan untuk berkumpul.

Sebagian besar responden anggota Gapoktan Kopi Arjuna menyatakan pernah mengikuti pembinaan dan pelatihan yang dilakukan oleh tim penyuluh setempat yaitu sebanyak 90\% responden anggota Gapoktan. Materi yang disampaikan pada saat pembinaan dan pelatihan adalah mengenai budidaya tanaman kopi, mengetahui cara membasmi hama dan penyakit, dan mendapatkan bantuan berupa alat perangkap untuk lalat buah serta obat untuk membasmi lalat.

\section{b. Analisis Manfaat Ekonomi Anggota Gapoktan Kopi Arjuna}

Manfaat ekonomi memberikan gambaran respon anggota terhadap aktivitas yang dilakukan oleh Gapoktan Kopi Arjuna. Kegiatan ekonomi yang dilakukan oleh Gapoktan Kopi Arjuna adalah kegiatan jaminan pemasaran kopi, jaminan harga jual kopi, peningkatan pendapatan, kemudahan dalam memperoleh saprotan dan bantuan kredit. Tanggapan anggota terhadap manfaat ekonomi yang dirasakan anggota dapat dilihat pada Tabel 2.

Tabel 2. Hasil Analisis Manfaat Ekonomi Anggota Gapoktan Kopi Arjuna

\begin{tabular}{|c|c|c|c|c|c|c|}
\hline \multirow{2}{*}{ No } & \multirow{2}{*}{$\begin{array}{c}\text { Indikator Manfaat } \\
\text { Ekonomi }\end{array}$} & \multicolumn{3}{|c|}{ Skor Manfaat } & \multirow{2}{*}{ Total Skor } & \multirow{2}{*}{ Kategori Manfaat } \\
\hline & & 1 & 2 & 3 & & \\
\hline 1 & Jaminan pemasaran kopi & 1 & 26 & 23 & 122 & Merasakan \\
\hline 2 & Jaminan harga jual kopi & 1 & 37 & 12 & 111 & Kurang Merasakan \\
\hline 3 & Peningkatan pendapatan & 1 & 28 & 21 & 120 & Merasakan \\
\hline 4 & $\begin{array}{l}\text { Kemudahan dalam } \\
\text { memperoleh Saprotan }\end{array}$ & 3 & 40 & 7 & 104 & Kurang Merasakan \\
\hline
\end{tabular}




\section{MIMBAR AGRIBISNIS}

Jurnal Pemikiran Masyarakat Ilmiah Berwawasan Agribisnis. 2017. 3(2): 150-168

Tabel 2 menunjukkan bahwa anggota Gapoktan merasakan jaminan pemasaran kopi dengan total skor 122 . Hal ini menunjukkan bahwa keberadaan Gapoktan Kopi Arjuna adalah sebagai wadah pengumpul atau penampungan kopi yang kemudian dipasarkan ke banyak mitra yang sudah terjalin dan pedagang besar lainnya. Setiap kopi yang dihasilkan oleh anggota Gapoktan diterima oleh Gapoktan Kopi Arjuna sesuai dengan kualitas yang ditentukan oleh pihak yang bermitra, meskipun tidak menjalin kontrak namun permintaan selalu ada. Namun, sampai saat ini Gapoktan Kopi Arjuna belum dapat memenuhi permintaan dalam jumlah yang banyak untuk setiap permintaan pasar.

Sebagian besar responden anggota Gapoktan Kopi Arjuna kurang merasakan jaminan harga jual kopi yang ditetapkan Gapoktan dengan total skor 111. Sebanyak $74 \%$ responden menyatakan bahwa harga yang ditetapkan lebih rendah dari harga di luar Gapoktan. Harga yang diterima anggota Gapoktan Kopi Arjuna berkisar antara Rp 6.000,- s/d Rp 6.500,- per kg cherry. Sedangkan, harga yang diterima oleh anggota Gapoktan dari luar Gapoktan Kopi Arjuna berkisar antara Rp 6.500,- s/d Rp 7.000,- per kg cherry. Oleh karena itu, terjadi persaingan harga yang mengakibatkan sebagian anggota
Gapoktan Kopi Arjuna kurang merasakan jaminan harga jual kopi.

Dalam hal adanya peningkatan pendapatan juga dirasakan responden anggota Gapoktan Kopi Arjuna dengan total skor 120 . Sebanyak $42 \%$ responden menyatakan bahwa pendapatan setelah menjadi anggota Gapoktan lebih besar daripada sebelum menjadi anggota. Berdasarkan analisis pendapatan, diperoleh hasil adanya peningkatan pendapatan rata-rata per responden sebesar Rp 13.845.295,- per musim panen. Perhitungan tersebut berdasarkan proksi jika produksi cherry per 1 pohon kopi sebanyak $5 \mathrm{~kg}$ dengan harga jual cherry sebesar Rp 6000,-. Sebanyak 56\% responden menyatakan kurang merasakan, hal ini karena adanya jaminan pemasaran dimana kopi yang dihasilkan anggota selalu diterima Gapoktan tanpa diiringi dengan peningkatan harga jual kopi.

Gapoktan Kopi Arjuna tidak menjalani unit bisnis dalam hal penyediaan saprotan. Sehingga sebanyak $80 \%$ responden kurang merasakan dalam kemudahan memperoleh saprotan. Para anggota Gapoktan membeli saprotan di toko pertanian yang berada di daerah Lembang. 
Hubungan Tingkat Partisipasi Anggota dengan Kinerja Gabungan Kelompok Tani INTAN GITA MUSTIKA, LIES SULISTYOWATI

2. Analisis Partisipasi Gapoktan Kopi Arjuna

a. Analisis Partisipasi Anggota Gapoktan Kopi Arjuna di Bidang Organisasi

Dalam perkembangan organisasi yang dijalankan Gapoktan Kopi Arjuna tidak terlepas dari partisipasi anggotanya. Tingkat partisipasi anggota Gapoktan Kopi
Arjuna dilihat dari partisipasi di bidang organisasi. Partisipasi anggota di bidang organisasi dilihat dari kehadiran dalam rapat, memberikan saran dalam rapat dan memanfaatkan fasilitas Gapoktan. Adapun hasil analisis partisipasi anggota di bidang organisasi Gapoktan Kopi Arjuna dapat dilihat pada Tabel 3.

Tabel 3. Hasil Analisis Partisipasi Anggota di Bidang Organisasi

\begin{tabular}{llcccccc}
\hline \multirow{2}{*}{ No } & Indikator Partisipasi & \multicolumn{3}{c}{ Skor Partisipasi } & \multirow{2}{*}{ Total Skor } & \multirow{2}{*}{ Kategori Partisipasi } \\
\cline { 3 - 5 } & & di Bidang Organisasi & 1 & 2 & 3 & & \\
\hline 1 & Kehadiran dalam rapat & 1 & 32 & 17 & 116 & Kurang Aktif \\
2 & Memberikan saran dalam rapat & 1 & 34 & 15 & 114 & Kurang Aktif \\
\hline
\end{tabular}

Berdasarkan hasil Tabel 3, terlihat bahwa secara keseluruhan partisipasi anggota dalam bidang organisasi dapat dikatakan kurang aktif. Dilihat dari kehadiran dalam rapat, sebanyak $64 \%$ responden kurang aktif/jarang menghadiri rapat. Hal ini berhubungan dengan status pekerjaan usahatani kopi mereka adalah pekerjaan sampingan. Sehingga menghadiri rapat yang diselenggarakan oleh pihak Gapoktan Kopi Arjuna hanya seperlunya saja, apabila mereka merasakan bahwa kehadiran mereka sangat dibutuhkan. Sebanyak $68 \%$ responden menanggapi bahwa mereka kurang aktif dalam memberikan saran saat rapat. Tingkat pendidikan dan rendahnya kepedulian menjadi penyebab ketidakaktifan anggota memberikan saran dalam rapat. Selanjutnya, dampak yang timbul akibat dari ketidakikutsertaannya anggota Gapoktan dalam memberikan saran menjadikan rendahnya tingkat pengetahuan pengurus terhadap kebutuhan yang diinginkan anggota Gapoktannya sendiri.

\section{b. Analisis Partisipasi Anggota Gapoktan Kopi Arjuna di Bidang Usaha}

Dalam perkembangan usaha yang dijalankan Gapoktan Kopi Arjuna tidak terlepas dari partisipasi anggotanya. Tingkat partisipasi anggota Gapoktan Kopi Arjuna dilihat dari partisipasi di bidang usaha. Bidang ini merupakan bidang yang menjadi tonggak dalam berjalannya kegiatan Gapoktan dalam menghasilkan keuntungan bersama sehingga dapat memberikan manfaat ekonomi yang dirasakan oleh anggota Gapoktan. 


\section{MIMBAR AGRIBISNIS}

Jurnal Pemikiran Masyarakat Ilmiah Berwawasan Agribisnis. 2017. 3(2): 150-168

Partisipasi anggota di bidang usaha dilihat

dari kegiatan menjual kopi ke Gapoktan

dan membeli saprotan di Gapoktan
Adapun hasil analisis partisipasi anggota

di bidang organisasi Gapoktan Kopi

Arjuna dapat dilihat pada Tabel 4.

Tabel 4. Hasil Analisis Partisipasi Anggota di Bidang Usaha

\begin{tabular}{clcccccc}
\hline \multirow{2}{*}{ No } & Indikator Partisipasi & \multicolumn{4}{c}{ Skor Partisipasi } & \multirow{2}{*}{ Total Skor } & \multirow{2}{*}{ Kategori Partisipasi } \\
\cline { 3 - 5 } & di Bidang Usaha & 1 & 2 & 3 & & Aktif \\
\cline { 3 - 5 } 2 & Menjual kopi ke Gapoktan & 0 & 30 & 20 & 120 & Kurang Aktif \\
\cline { 5 - 6 } & $\begin{array}{l}\text { Memperoleh saprotan dari } \\
\text { Gapoktan }\end{array}$ & 10 & 40 & 0 & 90 & \\
\hline
\end{tabular}

Berdasarkan Tabel 4, partisipasi anggota dalam menjual kopi ke Gapoktan dinilai aktif dengan skor yang diperoleh 120. Sebanyak $40 \%$ responden menyatakan bahwa mereka aktif menjual kopi ke Gapoktan. Mereka menjual seluruh hasil panennya ke Gapoktan, artinya mereka sangat merasakan jaminan pemasaran yang dilakukan oleh Gapoktan. Namun terdapat $60 \%$ responden yang kurang aktif dalam menjual kopinya ke Gapoktan. Meski begitu, mereka masih menjual kopinya ke Gapoktan namun hanya sebagian, sebagian lainnya dijual ke broker dan pembeli perseorangan yang langsung mendatangi mereka dengan menawarkan harga jual yang lebih tinggi dibandingkan harga yang ditawarkan oleh Gapoktan.

Sebanyak $\quad 80 \% \quad$ responden menyatakan kurang aktif membeli saprotan di Gapoktan, karena pihak Gapoktan sama sekali tidak melakukan jual-beli saprotan. Gapoktan hanya menjadi perantara dalam menyalurkan bantuan pengadaan saprotan dari pemerintah. Para anggota Gapoktan biasanya membeli saprotan di toko pertanian yang berada di daerah Lembang.

\section{Analisis Kinerja Gapoktan}

\section{a. Unit Usahatani}

Fungsi Gapoktan sebagai unit usahatani belum mampu dalam mengambil keputusan untuk pengembangan usaha kopi. Seperti dalam hal: belum tercapainya harga jual yang kompetitif, kuantitas yang belum bisa memenuhi permintaan serta belum terpenuhinya kualitas yang sesuai dengan spesifikasi dari pihak yang bermitra. Gapoktan juga kurang mampu dalam menyusun rencana dalam meningkatkan produksi kopi, hal ini dikarenakan kurangnya partisipasi anggota Gapoktan dalam menghadiri rapat. Selain itu, kurangnya keaktifan anggota Gapoktan dalam memberi saran yang disebabkan oleh keterbatasan pengetahuan anggota akan pentingnya sebuah perencanaan. Sehingga dalam penyusunan rencana 
Hubungan Tingkat Partisipasi Anggota dengan Kinerja Gabungan Kelompok Tani INTAN GITA MUSTIKA, LIES SULISTYOWATI

dalam meningkatkan produksi kopi kurang

tepat sasaran.

Tabel 5. Hasil Analisis Kinerja Gapoktan sebagai Unit Usahatani

\begin{tabular}{|c|c|c|c|c|c|c|c|}
\hline \multirow{2}{*}{ No } & \multirow{2}{*}{\multicolumn{2}{|c|}{ Indikator Unit Usahatani }} & \multicolumn{3}{|c|}{ Skor Kinerja } & \multirow{2}{*}{$\begin{array}{l}\text { Total } \\
\text { Skor }\end{array}$} & \multirow{2}{*}{ Kategori Kinerja } \\
\hline & & & 1 & 2 & 3 & & \\
\hline 1 & $\begin{array}{l}\text { Mengambil keputusan } \\
\text { pengembangan usaha kopi }\end{array}$ & untuk & 1 & 39 & 10 & 109 & Kurang Mampu \\
\hline 2 & $\begin{array}{l}\text { Menyusun } \quad \text { rencana } \\
\text { meningkatkan produksi kopi }\end{array}$ & dalam & 1 & 37 & 12 & 111 & Kurang Mampu \\
\hline 3 & $\begin{array}{l}\text { Meningkatkan kesinar } \\
\text { produktivitas dan kelestarian }\end{array}$ & $\begin{array}{l}\text { bungan } \\
\text { DA }\end{array}$ & 1 & 35 & 14 & 113 & Kurang Mampu \\
\hline
\end{tabular}

Perihal

meningkatkan

kesinambungan produktivitas dan kelestarian SDA juga belum mampu, karena semua anggota Gapoktan masih menggunakan bahan kimia untuk memperbanyak produksi kopinya. Ketua Gapoktan sudah memberikan arahan kepada anggota Gapoktan untuk mengurangi jumlah pemakaian bahan kimia, namun tidak semua anggota tidak mengikuti arahan tersebut. Anggota Gapoktan berpikir bahwa dengan menggunakan bahan kimia sebagai pupuknya akan lebih maksimal hasilnya dibandingkan memakai organik. Jika menggunakan pupuk berbahan kimia bisa menggunakan sedikit saja, sedangkan jika menggunakan pupuk berbahan organik diperlukan dalam jumlah yang banyak. Sedangkan akses menuju kebun sulit, sehingga tidak memungkinkan mengangkut bahan organik terlalu banyak.

\section{b. Unit Usaha Pengelolaan}

Fungsi Gapoktan sebagai unit usaha pengelolaan hanya mampu dalam menyusun perencanaan kebutuhan peralatan pengolahan, namun realisasinya tidak ada. Hal ini juga disebabkan kurangnya keaktifan anggota Gapoktan dalam rapat dan pemberian saran dalam rapat. Sehingga Gapoktan Kopi Arjuna tidak bisa mengetahui kebutuhan peralatan pengolahan yang dibutuhkan oleh anggota Gapoktan. Saat ini peralatan yang ada hanyalah dari bantuan pemerintah. Meskipun peralatan yang diberikan sudah cukup memadai namun tetap saja peralatan yang diberikan tidak mengikuti perkembangan teknologi masa kini. Peralatan yang digunakan masih manual, yaitu menggunakan tenaga manusia bukan menggunakan tenaga listrik. 
Jurnal Pemikiran Masyarakat Ilmiah Berwawasan Agribisnis. 2017. 3(2): 150-168

Tabel 6. Hasil Analisis Kinerja Gapoktan sebagai Unit Usaha Pengelolaan

\begin{tabular}{clcccccc}
\hline No & Indikator Unit Usaha Pengelolaan & \multicolumn{3}{c}{ Skor Kinerja } & Total \\
\cline { 3 - 4 } & 1 & 2 & 3 & Skor & Kategori Kinerja \\
\hline 1 & $\begin{array}{l}\text { Menyusun perencanaan kebutuhan } \\
\text { peralatan pengolahan }\end{array}$ & 1 & 37 & 12 & 111 & Kurang Mampu \\
2 & $\begin{array}{l}\text { Mengembangkan kemampuan anggota } \\
\text { dalam pengolahan kopi }\end{array}$ & 0 & 39 & 11 & 111 & Kurang Mampu \\
3 & $\begin{array}{l}\text { Kemampuan dalam melakukan proses } \\
\text { nilai tambah pengelolaan kopi }\end{array}$ & 1 & 43 & 6 & 105 & Kurang Mampu \\
$\begin{array}{l}\text { Mengevaluasi kegiatan dan rencana } \\
\text { kebutuhan anggota }\end{array}$ & 2 & 39 & 9 & 107 & Kurang Mampu \\
\hline
\end{tabular}

Mengembangkan kemampuan anggota dalam pengolahan kopi, pihak Gapoktan sudah mengikutsertakan anggotanya dalam beberapa pelatihan bahkan studi banding yang diselenggarakan oleh pihak pemerintah. Namun kembali lagi kepada latar belakang pendidikan anggota Gapoktan yang mayoritas adalah lulusan Sekolah Dasar (SD). Hal ini menjadi hambatan berupa kurangnya tingkat pemahaman dari kegiatan yang telah diadakan oleh Gapoktan. Berkaitan dengan kemampuan proses nilai tambah pengelolaan kopi juga masih kurang mampu. Meskipun sebagian besar anggota Gapoktan mengetahui berbagai macam olahan dari kopi, mereka enggan untuk mengolah kopi menjadi berbagai olahan. Disebabkan karena proses pengolahan yang lama dan minimnya peralatan maka sebagian anggota hanya memproduksi kopi berasan saja. Dalam mengevaluasi kegiatan dan rencana kebutuhan anggota juga belum mampu berjalan sesuai dengan harapan Gapoktan, karena kurangnya partisipasi anggoa yang hadir dalam rapat dan kurangnya dalam memberikan saran dan pendapat.

\section{c. Unit Usaha Sarana dan Prasarana Produksi}

Fungsi Gapoktan sebagai unit sarana dan prasarana produksi, dalam menyediakan saprotan dapat dikatakan kurang mampu. Ketua Gapoktan juga membenarkan hal itu, Gapoktan sama sekali tidak menyediakan bahkan menjual saprotan karena keterbatasan modal. Gapoktan hanya menyalurkan saprotan yang berasal dari bantuan pemerintah saja, sehingga para anggota Gapoktan membeli saprotan di toko pertanian terdekat. Bahkan menyusun rencana kebutuhan saprotan pun dapat dikatakan kurang mampu. Anggota Gapoktan merasa tidak perlu dilakukan penyusunan rencana kebutuhan saprotan jika Gapoktan tidak menjual saprotan. 
Hubungan Tingkat Partisipasi Anggota dengan Kinerja Gabungan Kelompok Tani INTAN GITA MUSTIKA, LIES SULISTYOWATI

Tabel 7. Hasil Analisis Kinerja Gapoktan sebagai Unit Usaha Sarana dan Prasarana Produksi

\begin{tabular}{|c|c|c|c|c|c|c|}
\hline \multirow{2}{*}{ No } & \multirow{2}{*}{$\begin{array}{l}\text { Indikator Unit Usaha } \\
\text { Sarana dan Prasarana }\end{array}$} & \multicolumn{3}{|c|}{ Skor Kinerja } & \multirow{2}{*}{$\begin{array}{l}\text { Total } \\
\text { Skor }\end{array}$} & \multirow{2}{*}{$\begin{array}{c}\text { Kategori } \\
\text { Kinerja }\end{array}$} \\
\hline & & 1 & 2 & 3 & & \\
\hline 1 & Menyediakan Saprotan & 8 & 42 & 0 & 107 & Kurang Mampu \\
\hline 2 & Menyusun rencana kebutuhan saprotan & 2 & 41 & 7 & 105 & Kurang Mampu \\
\hline 3 & Memfasilitasi prasarana untuk anggota & 6 & 39 & 5 & 99 & Kurang Mampu \\
\hline
\end{tabular}

Mengenai fasilitas sarana yang dimiliki Gapoktan saat ini hanyalah alatalat yang berasal dari bantuan pemerintah. Fasilitas prasarana, Gapoktan tidak memiliki kantor Gapoktan. Selama ini jika ada rapat berkumpul di rumah ketua Gapoktan, sebagian peralatan juga disimpan di rumah ketua Gapoktan. Namun Gapoktan sedang membangun bangunan untuk pengolahan kopi, meskipun didirikan di tanah milik ketua kelompok tani.

\section{d. Unit Usaha Pemasaran}

Berdasarkan hasil tanggapan responden anggota Gapoktan Kopi Arjuna menunjukkan bahwa, seluruh indikator unit usaha pemasaran termasuk kategori kurang mampu. Kategori yang dimaksud adalah menganalisis potensi pasar, menjalin kerjasama/mitra, dan merencanakan kebutuhan pasar dengan memperhatikan segmentasi pasar.

Tabel 8. Hasil Analisis Kinerja Gapoktan sebagai Unit Usaha Pemasaran

\begin{tabular}{|c|c|c|c|c|c|c|}
\hline \multirow{2}{*}{ No } & \multirow{2}{*}{ Indikator Unit Usaha Pemasaran } & \multicolumn{3}{|c|}{ Skor Kinerja } & \multirow{2}{*}{$\begin{array}{l}\text { Total } \\
\text { Skor }\end{array}$} & \multirow{2}{*}{$\begin{array}{l}\text { Kategori } \\
\text { Kinerja }\end{array}$} \\
\hline & & 1 & 2 & 3 & & \\
\hline 1 & Menganalisis potensi pasar & 2 & 37 & 11 & 109 & $\begin{array}{l}\text { Kurang } \\
\text { Mampu }\end{array}$ \\
\hline 2 & Menjalin kerjasama/mitra & 3 & 40 & 7 & 104 & $\begin{array}{l}\text { Kurang } \\
\text { Mampu }\end{array}$ \\
\hline 3 & $\begin{array}{l}\text { Merencanakan kebutuhan pasar dengan } \\
\text { memperhatikan segmentasi pasar }\end{array}$ & 3 & 40 & 7 & 104 & $\begin{array}{l}\text { Kurang } \\
\text { Mampu }\end{array}$ \\
\hline
\end{tabular}

Ketua Gapoktan menjelaskan bahwa Gapoktan sudah mampu dalam menganalisis potensi pasar, hal ini karena Gapoktan memiliki marketing inteligent. Dimana Gapoktan mampu meneliti serta berupaya menggali bahkan mencari informasi mengenai harga jual dan pasar. Ketua Gapoktan juga menghadiri acara pelatihan pasar ekspor yang diselenggarakan oleh Kemendag. Para perwakilan Gapoktan di Jawa Barat berkumpul dan dipertemukan dengan para eksportir. Dengan kegiatan tersebut Gapoktan mendapatkan informasi pasar ekspor dan telah menjalin kerjasama dengan para eksportir bahkan perusahaan 


\section{MIMBAR AGRIBISNIS}

Jurnal Pemikiran Masyarakat Ilmiah Berwawasan Agribisnis. 2017. 3(2): 150-168

kopi di beberapa negara. Kini Gapoktan juga telah menjalin mitra denga 4 perusahan kopi di Indonesia, diantaranya adalah PT. Taman Delta, PT. Sarimakmur, PT. Indokom dan PT. Kopindo.

Dalam menentukan kebutuhan pasar dengan memperhatikan segmentasi pasar, kepala seksi pemasaran Gapoktan Kopi Arjuna meneliti kondisi pasar. Melihat potensi pasar baik dalam negeri maupun dalam negeri dengan menjalin komunikasi yang baik dengan mitra maupun pihak pemerintah. Sebagaimana kajian Sulistyowati (2012) yang menyimpulkan bahwa pemasaran produk kopi di pasar lokal perlu ditingkatkan melalui upaya menjalin kemitraan dengan café-cafe yang banyak berkembang di Kota Bandung. Kini Gapoktan Kopi Arjuna sedang memperluas segmentasi pasar pada kalangan remaja. Promosi produk kopi Gapoktan menggunakan media sosial seperti instagram. Selain itu, promosi juga dilakukan dari mulut ke mulut. Ketua Gapoktan Kopi Arjuna mendirikan kedai kopi yang berdekatan dengan kawasan wisata Lembang. Namun kini Gapoktan sedang berusaha menyusun rencana agar kebutuhan pasar dapat terpenuhi, dengan memperluas kebun kopi dan menanam sebanyak 360.000 pohon.
Ketidakselarasan antara hasil tanggapan responden anggota Gapoktan dengan penjelasan dari ketua Gapoktan disebabkan kurangnya transparansi informasi kepada anggota Gapoktan, sehingga anggota Gapoktan tidak mengetahui upaya yang telah dilakukan Gapoktan dalam kegiatan pemasaran. Kurangnya antusias anggota Gapoktan dalam mencari informasi pemasaran saat ini.

\section{e. Unit Usaha Keuangan Mikro}

Fungsi Gapoktan sebagai unit usaha keuangan mikro dikatakan kurang mampu bahkan cenderung tidak mampu. Gapoktan tidak menyediakan peminjaman modal dikarenakan kondisi permodalan Gapoktan yang kurang. Sehingga, Gapoktan tidak mempunyai jaminan jika sewaktu-waktu perguliran uang pinjaman tidak berjalan sesuai dengan kesepakatan. Selain itu, ada peluang pembiayaan dari perbankan, namun bunga yang ditawarkan oleh pihak bank sangat tinggi, sehingga dikhawatirkan anggota tidak dapat memenuhi kewajiban pelunasannya secara tepat waktu karena pendapatan petani kopi tidak menentu waktu maupun nilainya. 
Hubungan Tingkat Partisipasi Anggota dengan Kinerja Gabungan Kelompok Tani INTAN GITA MUSTIKA, LIES SULISTYOWATI

Tabel 9. Hasil Analisis Kinerja Gapoktan sebagai Unit Usaha Keuangan Mikro

\begin{tabular}{clcccccc}
\hline \multirow{2}{*}{ No } & \multicolumn{1}{c}{ Indikator Unit Usaha } & \multicolumn{3}{c}{ Skor Kinerja } & \multirow{2}{*}{ Total Skor } & \multirow{2}{*}{ Kategori Kinerja } \\
\cline { 3 - 5 } & & Keuangan Mikro & 1 & 2 & 3 & & \\
\cline { 3 - 5 } 1 & Menyediakan peminjaman modal & 13 & 37 & 0 & 90 & Kurang Mampu \\
2 & $\begin{array}{l}\text { Memberikan informasi untuk } \\
\text { mengakses permodalan }\end{array}$ & 7 & 37 & 6 & 99 & Kurang Mampu \\
\hline
\end{tabular}

Gapoktan berupaya dalam memberikan informasi untuk mengakses permodalan jika terdapat anggotanya yang membutuhkan informasi tersebut. Kini permodalan Gapoktan hanya berasal dari mitra-mitra serta buyer yang telah bekerjasama dengan Gapoktan Kopi Arjuna.

\section{Analisis Hubungan Manfaat dengan Tingkat Partisipasi Anggota Gapoktan}

Hubungan antara manfaat yang diperoleh anggota dengan tingkat partisipasi anggota dianalisis menggunakan uji korelasi Rank Spearman. Untuk dapat mengetahui kuat lemahnya tingkat atau derajat keeratan hubungan antara variabel-variabel yang diteliti, digunakan tabel kriteria pedoman untuk koefisien korelasi (Sugiyono, 2012).

Tabel 10. Pedoman untuk Memberikan Interpretasi Koefisien Korelasi

\begin{tabular}{cc}
\hline $\begin{array}{c}\text { Interval Koefisien } \\
\text { Korelasi }\end{array}$ & $\begin{array}{c}\text { Tingkat } \\
\text { Hubungan }\end{array}$ \\
\hline $0,000-0,199$ & Sangat Lemah \\
$0,200-0,399$ & Lemah \\
$0,400-0,599$ & Sedang \\
$0,600-0,799$ & Kuat \\
$0,800-1,000$ & Sangat Kuat \\
\hline
\end{tabular}

Hasil analisis bisa dilihat pada Tabel 11.

Tabel 11. Hasil Analisis Rank Spearman Hubungan antara Manfaat Sosial dengan Tingkat Partisipasi Organisasi dan Usaha Anggota Gapoktan Kopi Arjuna

\begin{tabular}{lc}
\hline \multicolumn{1}{c}{ Manfaat } & $\begin{array}{c}\text { Tingkat } \\
\text { Partisipasi }\end{array}$ \\
\hline Koefisien korelasi $\left(\mathrm{r}_{\mathrm{s}}\right)$ & $0.360^{*}$ \\
Sig (2-tailed) & 0.010 \\
$\mathrm{~N}$ & 50 \\
${ }^{*}$ Correlation is significant at the 0,05 \\
level (2-tailed) \\
Dari hasil perhitungan diperoleh
\end{tabular}
nilai signifikansi sebesar $0,010<\alpha(0,05)$, maka hipotesis kerja $\left(\mathrm{H}_{1}\right)$ diterima. Artinya terdapat hubungan yang signifikan antara manfaat yang diperoleh anggota dengan tingkat partisipasi anggota Gapoktan Kopi Arjuna. Hubungan ini ditunjukkan dengan nilai korelasi sebesar 0,360 yang termasuk ke dalam kategori lemah (0,20-0,399).

Hasil penelitian yang dilakukan Ginting (2003) menunjukkan bahwa hubungan manfaat yang diperoleh anggota dan tingkat partisipasi anggota dikategorikan pada hubungan yang lemah. Hal ini dikarenakan kurangnya manfaat ekonomi yang dirasakan anggota dalam 


\section{MIMBAR AGRIBISNIS}

Jurnal Pemikiran Masyarakat Ilmiah Berwawasan Agribisnis. 2017. 3(2): 150-168

ketersediaan peminjaman modal, sedangkan tingkat partisipasi termasuk dalam kategori tinggi. Dalam penelitian ini berlaku sebaliknya, manfaat ekonomi dirasakan oleh anggota sedangkan tingkat partisipasi termasuk kategori kurang aktif. Hal tersebut yang menyebabkan hubungan antar keduanya termasuk ke dalam kategori hubungan yang lemah.

Berbeda dengan hasil penelitian Dartiana (2005), tingkat keeratan antara manfaat dengan tingkat partisipasi menunjukkan hubungan yang kuat. Terlihat dari anggota yang merasakan manfaat ekonomi dengan tingkat partisipasi yang aktif. Dapat disimpulkan bahwa semakin tinggi manfaat yang diperoleh maka keinginan berpartisipasi juga tinggi.

Dalam penelitian ini menunjukkan bahwa masih terdapat manfaat yang kurang dirasakan oleh anggota sehingga partisipasi anggota menjadi kurang aktif. Sehingga, hubungan antara manfaat dengan tingkat partisipasi termasuk dalam kategori lemah.

\section{Analisis Hubungan Tingkat Partisipasi Anggota dengan Kinerja Gapoktan}

Hubungan antara tingkat partisipasi anggota dengan kinerja Gapoktan dianalisis menggunakan uji korelasi Rank Spearman. Data yang diperoleh adalah berupa data ordinal yang diperoleh dari angker dengan jenis skala Likert. Untuk dapat mengetahui kuat lemahnya tingkat atau derajat keeratan hubungan antara variabel-variabel yang diteliti, digunakan Tabel 11 kriteria pedoman untuk koefisien korelasi (Sugiyono, 2012).

Tabel 12. Hasil Analisis Rank Spearman Hubungan antara Tingkat Partisipasi Anggota dengan Kinerja Gapoktan Kopi Arjuna

\begin{tabular}{lc}
\hline \multicolumn{1}{c}{ Tingkat Partisipasi } & Kinerja Gapoktan \\
\hline $\begin{array}{l}\text { Koefisien korelasi } \\
\left(\mathrm{r}_{\mathrm{s}}\right)\end{array}$ & $0,306^{*}$ \\
$\mathrm{Sig}(2$-tailed) & 0,031 \\
$\mathrm{~N}$ & 50 \\
${ }^{*}$ Correlation is significant at the 0,05 \\
level (2-tailed)
\end{tabular}

Dari hasil perhitungan diperoleh nilai signifikansi sebesar $0,031<\alpha(0,05)$, maka hipotesis kerja $\left(\mathrm{H}_{1}\right)$ diterima. Artinya terdapat hubungan yang signifikan antara tingkat partisipasi anggota dengan kinerja Gapoktan Kopi Arjuna. Hubungan ini ditunjukkan dengan nilai korelasi sebesar 0,306 yang termasuk ke dalam kategori lemah $(0,20-0,399)$.

Kondisi tersebut sejalan dengan hasil penelitian Fauziyah, dkk (2011), bahwa hubungan tingkat partisipasi dengan kinerja Gapoktan masuk ke dalam kategori lemah. Hal tersebut disebabkan ketidakjelasan siapa anggota Gapoktan, apakah hanya pengurus poktan ataukah seluruh anggota Gapoktan. Sosialisasi perlu dilakukan untuk memberikan 
Hubungan Tingkat Partisipasi Anggota dengan Kinerja Gabungan Kelompok Tani INTAN GITA MUSTIKA, LIES SULISTYOWATI

pengertian kepada seluruh anggota Gapoktan bahwa tanpa adanya partisipasi dari seluruh anggota Gapoktan di setiap kegiatan yang dilakukan, maka Gapoktan tidak dapat menjalankan fungsinya. Dalam penelitian ini kurangnya kesadaran berpartisipasi dalam kehadiran rapat dan memberikan saran termasuk dalam kategori kurang aktif, sehingga menyebabkan fungsi Gapoktan tidak berjalan secara optimal.

\section{PENUTUP}

Manfaat yang diperoleh anggota Gapoktan Kopi Arjuna yang berada pada kategori merasakan adalah kerjasama yang baik dengan pengurus, hubungan yang baik dengan sesama anggota, kegiatan pembinaan dan pelatihan, jaminan pemasaran kopi dan peningkatan pendapatan. Tingkat partisipasi anggota yang berada pada tingkat partisipasi yang aktif adalah menjual kopi ke Gapoktan. Manfaat yang diperoleh anggota dengan tingkat partisipasi anggota Gapoktan Kopi Arjuna menunjukkan hubungan yang signifikan, yang termasuk dalam kategori korelasi yang lemah. Tingkat partisipasi anggota dengan kinerja Gapoktan Kopi Arjuna menunjukkan hubungan yang signifikan, yang termasuk dalam kategori korelasi yang lemah.

Berdasarkan kesimpulan di atas, maka direkomendasikan beberapa hal sebagai berikut: (1) Perlu penguatan peran para pengurus Gapoktan Kopi Arjuna dengan merekrut SDM yang lebih kompeten baik dalam penguasaan teknologi serta keterampilan dalam menjalankan tugas sesuai jabatannya. Mengikutsertakan para pengurus dalam segala kegiatan yang diselenggarakan oleh pemerintah, (2) Transparansi informasi dengan semua anggota Gapoktan perlu dilakukan agar menjaga kepercayaan para anggota Gapoktan dalam partisipasi di bidang usaha dan organisasi. Dengan begitu para anggota akan lebih merasakan adanya manfaat ekonomi dan sosial selama bergabung dengan Gapoktan Kopi Arjuna, (3) Manajemen kontrol perlu ditingkatkan oleh ketua Gapoktan untuk melihat apakah segala kegiatan yang telah dilaksanakan telah sesuai dengan rencana dan juga untuk menentukan rencana kerja yang akan datang, dan (4) Pemasaran produk Gapoktan Kopi Arjuna di pasar lokal perlu ditingkatkan, melalui upaya menjalin kemitraan dengan cafe-cafe yang banyak berkembang di Bandung. Karena pasar lokal juga memiliki potensi yang tinggi, dimana mengkonsumsi kopi sudah menjadi budaya bangsa Indonesia.

\section{DAFTAR PUSTAKA}

Deptan. 2007. Peraturan Menteri Pertanian No. 2007. 
Jurnal Pemikiran Masyarakat Ilmiah Berwawasan Agribisnis. 2017. 3(2): 150-168

Departemen Kemenetrian Pertanian.

Jakarta.

Deptan. 2013. Peraturan menteri Pertanian

No. $\quad$ 82/Permentan/OT.140/8/2013.

Departemen Kementerian Pertanian.

Jakarta

Depnaker. 2003. Undang-Undang Tenaga

Kerja No. 13 Tahun 2003. Departemen

Tenaga Kerja. Jakarta.

Fauziah Y, Aida Vitalaya dan Richard

W.E. Lumintang. 2011. Kinerja

Gabungan Kelompok Tani Kasus:

Kabupaten Lampung Selatan Provinsi

Lampung. Junal Penyuluhan:

September 2011, Vol.7 No.2.

Gapoktan Kopi Arjuna. 2015. Profil

Gapoktan Kopi Arjuna. Bandung:

Gapoktan Kopi Arjuna.

Ginting IR. 2003. Analisis Keragaan

Koperasi Kredit dan Tingkat

Partisipasi Anggota (Studi Kasus

Koperasi Kredit Sejahtera, Cibinong.

Skripsi. Bogor: Institut Pertanian

Bogor.

Sugiyono. 2012. Metode Penelitian

Kuantitatif Kualitatif dan $R \& D$.

Bandung: Alfabeta.

Sulistyowati, L. 2012. Partnership

Development Of Coffee Farmers

Group In Facing The Global Market

(Case Study on the Coffee Farmers

Group "RahayuTani", Bandung West

Java). Proceding International

Conference on Small-scale Producer
Agency in the Globalized Market.

Faculty of Agriculture, Padjadjaran

University. Bandung.Indonesia. 